\title{
Alcohol consumption and sensory threshold differences between C57BL/6J and DBA/2J mice
}

\author{
J. K. BELKNAP, R. R. COLEMAN, and K. FOSTER \\ University of Texas, Austin, Texas 78712
}

\begin{abstract}
Using a lithium induced taste-aversion paradigm with varying concentrations of alcohol (ethanol), C57BL/6J mice showed a higher avoidance threshold than DBA/2J mice, thus indicating that the large strain differences in ethanol preference reported in the literature may be, to some extent, caused by strain differences in the stimulus saliency of ethanol solutions.
\end{abstract}

When presented with a choice between an ethanol (alcohol) solution and water, large inbred strain differences have been observed in voluntary ethanol consumption. The largest differences have been between DBA mice, which consume almost no ethanol, and C57 mice, which consume more of a $10 \%$ ethanol solution than water. Under two-bottle choice conditions ( $10 \%$ ethanol vs. water), C57 mice voluntarily consume more than $10 \mathrm{~g} / \mathrm{kg} /$ day of ethanol, while DBA mice consume only a fraction of this amount, usually .1 to $2 \mathrm{~g} / \mathrm{kg} /$ day (Fuller, 1964; McClearn, 1968; Rodgers, 1972). C57 mice frequently consume ethanol in amounts approaching their metabolic capacity, while DBAs consume only a small fraction of this amount (Rodgers, 1972; Thiessen, Whitworth, \& Rodgers, 1966, 1967).

Considerable research effort has been focused on the mechanisms responsible for the regulation of ethanol intake in C57 and DBA mice. Several possibilities have been proposed and investigated, such as strain differences in rates of metabolism and associated hepatic enzyme activities (Rodgers, McClearn, Bennett, \& Hebert, 1963; Schlesinger, 1966; Thiessen et al., 1966, 1967), neural sensitivity to the intoxicating effects of ethanol (Belknap, Belknap, Berg, \& Coleman, 1977; Schneider, Evans, Chenoweth, \& Beeman, 1973), and toxic acetaldehyde accumulation following ethanol ingestion (Horowitz \& Whitney, 1975; Schlesinger, Kakihana, \& Bennett, 1966; Sheppard, Albersheim, \& McClearn, 1968, 1970). All of these proposed mechanisms assume that the ingestion of ethanol is more aversive for DBA mice than for C57 mice, and that the aversive consequences occur after the ethanol has been absorbed into the bloodstream from the gastrointestinal tract

This work was supported by NIDA Grants DA 01215 and DA 01800 awarded to J. K. Belknap. (postabsorptive mechanisms). In contrast, possible preabsorptive aversive mechanisms (those operating prior to the absorption of ethanol into the blood), such as taste, odor, and mucosal irritation, have been relatively little studied experimentally, even though the suggestion has often been made that they may be important (Fuller, 1967; LeMagnen, 1972; Nachman, LaRue, \& LeMagnen, 1971; Rodgers, 1972; Rodgers \& McClearn, 1962; Wilson, 1972).

The intent of the present report is to present evidence that there are strain differences in sensory or perceptual capacities with respect to ethanol solutions. The approach used was to determine strain differences in the capacity to develop a lithiuminduced conditioned aversion to the taste of ethanol. The development of an aversion to a given ethanol concentration is presumptive evidence that the animals can discriminate the ethanol solution from pure water. The stimulus saliency of ethanol ingestion for DBA and C57 mice could then be estimated using a single-bottle technique patterned after that of Nachman et al. (1971).

\section{METHOD}

The mice (total $\mathrm{N}=208$ ) of both strains were obtained from Jackson Laboratories (Bar Harbor, Maine) in lots of 50-53 mice (comprising 6 to 10 litters) per shipping carton at 5 weeks of age. These animals were housed 4 per cage on an essentially random assignment basis, with any one mouse having essentially the same likelihood of being housed in a particular cage as any other mouse. Nine to 12 weeks later, each mouse was randomly assigned to one of the 13 treatment groups. This two-stage randomization process makes it extremely unlikely that members of any one group were littermates. All of the mice were placed on a restricted water access schedule ( 90 min each day) for 4 days to insure that the animals would drink promptly and freely upon introduction of the water bottles. On the fifth day, groups of 8 mice of each strain were given $10 \mathrm{~min}$ access to an ethanol solution (pretest), followed $3 \mathrm{~min}$ later by an IP $3.0 \mathrm{mEq} / \mathrm{kg}$ dose of isotonic $(.15 \mathrm{M})$ $\mathrm{LiCl}$. Each group was exposed to a single ethanol concentration, which varied between groups from $0 \%$ to $7 \%(\mathrm{v} / \mathrm{v})$. An addi- 
tional group from each strain was exposed to $15 \%$ sucrose. On Days 6 through 8, the animals were restabilized on the 90-min daily water access schedule, followed, on Day 9 , by a 10-min reexposure (posttest) to the same ethanol (or sucrose) concentration as was given on Day 5. Food was freely available throughout the experiment except for these 10-min test periods. Ethanol-only groups ( $\mathrm{no} \mathrm{LiCl}$ ) were also run for varying ethanol concentrations from $0 \%$ to $10 \%(\mathrm{v} / \mathrm{v})$ ethanol $(\mathrm{N}=8$ per group) to assess the aversive properties of the initial ethanol exposure alone. These animals were treated identically to the lithium-treated animals, except that no injections were given. Each group was exposed to only a single ethanol concentration.

Conditioned aversions were assessed by comparing the posttest (Day 9) consumption with the pretest (Day 5) consumption for each group. Two-tailed $t$ tests were used to assess statistical significance based on paired differences $(\mathrm{df}=7)$. All fluids were freshly prepared from $95 \%$ ethanol and distilled water and administered in the animal's home cage at 3 to $4 \mathrm{~h}$ after light onset on a 12L:12D light schedule. Inverted $25-\mathrm{ml}$ graduated cylinders were used which were accurate to the nearest $.1 \mathrm{ml}$.

\section{RESULTS}

The results for the lithium-treated groups are shown in Table 1. The C57 mice developed a significant lithium-induced aversion to only the two higher ethanol concentrations $(6.5 \%$ and $7 \%)$. The ethanol detection threshold for the C57 mice by this method was between the $5 \%(\mathrm{t}=.42$, n.s. $)$ and $6.5 \%(5=3.41, \mathrm{p}<.05)$ concentrations. The DBA mice, on the other hand, developed a significant aversion to every ethanol concentration at, or above, the $2 \%$ concentration. The ethanol detection threshold for the DBA animals was between the $1 \%(\mathrm{t}=.95$, n.s.) and $2 \%(\mathrm{t}=2.39, \mathrm{p}<.05)$ concentrations, or less than $1 / 3$ that seen in the C57 mice. Both strains developed a roughly equal aversion to the $15 \%$ sucrose solution (C57, $t=4.40, p<.01 ; D B A, t=3.60$, $\mathrm{p}<.01$ ), indicating that both strains are fully capable of forming conditioned aversions under these conditions.

Results from the ethanol-only groups (no $\mathrm{LiCl}$ ) are shown in Table 2. These groups were deemed of interest because the pretest ethanol exposure often produced a readily observable degree of overt intoxication. Ethanol solutions of $4 \%$ or above produced staggering, stumbling, reeling, and falling on the back in animals of both strains. Loss of the righting reflex occurred in some of the animals exposed to the $10 \%$ concentration. As can be seen in Table 2, the ethanol dosages $(\mathrm{g} / \mathrm{kg})$ were quite substantial at the higher ethanol fluid concentrations, and are potentially capable of producing a conditioned aversion in the absence of lithium treatment. The C57 mice developed no significant aversions to any of the ethanol concentrations except for the highest concentration employed $(10 \%)$. The DBA mice developed significant aversions to the three highest concentrations $(6 \%, 8 \%$, and $10 \%)$, but not to the lower ones.

Table 1

Mean $( \pm \mathrm{SD})$ Ethanol Consumption (Milliliters) for the LiCl-Injected Groups Presented with Varying Concentrations of Ethanol

\begin{tabular}{lccrc}
\hline & \multicolumn{2}{c}{ C57BL/6J } & \multicolumn{2}{c}{ DBA/2J } \\
\cline { 2 - 5 } Test Fluid & \multicolumn{1}{c}{ Pretest } & Posttest & Pretest & Posttest \\
\hline $0 \%$ EtOH & $1.18 \pm .33$ & $1.25 \pm .42$ & $1.22 \pm .32$ & $1.19 \pm .35$ \\
$1 \%$ EtOH & & & $.96 \pm .23$ & $.84 \pm .29$ \\
$2 \%$ EtOH & $1.08 \pm .42$ & $1.09 \pm .26$ & $.98 \pm .41$ & $.61 \pm .25^{*}$ \\
$3 \%$ EtOH & $.98 \pm .17$ & $.84 \pm .33$ & $.91 \pm .40$ & $.36 \pm .20^{*}$ \\
$5 \%$ EtOH & $.96 \pm .25$ & $.89 \pm .24$ & $.67 \pm .25$ & $.06 \pm .10 \dagger$ \\
$6.5 \%$ EtOH & $1.02 \pm .32$ & $.50 \pm .27 *$ & $.69 \pm .21$ & $.10 \pm .15 \dagger$ \\
$7 \%$ EtOH & $.98 \pm .20$ & $.31 \pm .20 \dagger$ & $1.42 \pm .47$ & $.65 \pm .38^{* *}$ \\
$15 \%$ Sucrose & $1.51 \pm .57$ & $.40 \pm .38 * *$ & $* * p<.01$
\end{tabular}

Table 2

Mean ( \pm SD) Ethanol Consumption (Milliliters) for the Groups Not Given LiCl

\begin{tabular}{ccccccc}
\hline & \multicolumn{3}{c}{ C57BL/6J } & \multicolumn{2}{c}{$\mathrm{DBA} / 2 \mathrm{~J}$} \\
\cline { 2 - 6 } Test Fluid & \multicolumn{1}{c}{ Pretest } & Posttest & $\mathrm{g} / \mathrm{kg} \dagger$ & $\mathrm{Pretest}$ & $\mathrm{Posttest}$ & $\mathrm{g} / \mathrm{kg} \dagger$ \\
\hline $0 \%$ EtOH & $1.20 \pm .30$ & $1.38 \pm .48$ & 0 & $1.15 \pm .30$ & $1.35 \pm .31$ & 0 \\
$2 \%$ EtOH & $1.11 \pm .25$ & $1.20 \pm .35$ & .7 & $.98 \pm .42$ & $1.13 \pm .29$ & .7 \\
$4 \%$ EtOH & $.99 \pm .36$ & $1.08 \pm .44$ & 1.4 & $1.06 \pm .39$ & $1.18 \pm .28$ & 1.5 \\
$6 \%$ EtOH & $1.10 \pm .29$ & $1.06 \pm .23$ & 2.3 & $.71 \pm .19$ & $.43 \pm .22 *$ & 1.6 \\
$7 \%$ EtOH & $1.09 \pm .20$ & $1.00 \pm .32$ & 2.5 & $.75 \pm .24$ & $.46 \pm .20^{*}$ & 1.8 \\
$10 \%$ EtOH & $.98 \pm .27$ & $.48 \pm .26 * *$ & 3.2 & $.66 \pm .26$ & $.26 \pm .19 * *$ & 2.2 \\
\hline
\end{tabular}

Note-Each value represents a mean of eight mice.

${ }^{*} p<.05$, pretest vs. posttest; ${ }^{* *} p<.01$ 
For both strains, the aversive effects of the ethanol alone (Table 2) were seen only at concentrations well above the detection thresholds estimated from Table 1. For the LiCl-injected DBA mice, the lowest ethanol concentration avoided $(2 \%)$ produced no overt signs of intoxication or conditioned aversion in the absence of $\mathrm{LiCl}$. The ingestion of $2 \%$ ethanol without $\mathrm{LiCl}$ (Table 2) produced results that were highly similar to the results obtained with pure water $(0 \% \mathrm{EtOH})$ based on the change from pretest to posttest. The $2 \%$ ethanol did not produce a conditioned aversion which could summate with the aversion produced by $\mathrm{LiCl}$, thus the detection threshold for DBAs estimated from Table 1 (between 1\% and $2 \%$ ) can be attributed to the effects of $\mathrm{LiCl}$ alone. Essentially the same situation exists with the LiClinjected $\mathrm{C} 57 \mathrm{~s}$ at the lowest ethanol concentration avoided $(6.5 \%)$, even though considerable signs of overt intoxication resulted from this concentration of ethanol. Thus, the large strain differences in detection thresholds were not confounded by possible strain differences in the aversive properties of ethanol intoxication.

\section{DISCUSSION}

The results show that the ethanol detection threshold is three- to fivefold higher in C57BL mice relative to DBA mice, as determined by lithiuminduced conditioned aversions. Nachman et al. (1971), using an experimental design similar to that used here, found that C57BL mice failed to develop a lithium-induced conditioned aversion to $6.7 \%$ ethanol, but readily formed conditioned aversions to $.1 \%$ saccharin or $15 \%$ sucrose under the same conditions. BALB/c mice (an ethanol avoiding strain) readily formed conditioned aversions to all three fluids. The failure to develop a lithium-induced conditioned aversion does not, by itself, prove that the ethanol test solution cannot be detected by the animals. However, the marked strain differences seen in the present study and in that of Nachman et al. (1971) strongly suggest that C57 mice (an ethanolpreferring strain) have greater difficulty detecting ethanol solutions than do DBA or $B A L B / c$ mice (ethanol-avoiding strains).

In the groups where $\mathrm{LiCl}$ was not employed, DBA mice developed a significant conditioned aversion to ethanol concentrations as low as $6 \%(1.6 \mathrm{~g} / \mathrm{kg})$, while the analogous ethanol concentration for the C57s was $10 \%(3.2 \mathrm{~g} / \mathrm{kg})$. This would suggest that DBA mice are more sensitive to the aversive effects of ethanol intoxication at these higher doses than are C57 mice. However, strain differences in the stimulus saliency of ethanol could also explain these findings, since conditioned aversions are facilitated as the stimulus saliency of the test fluid increases (Kalat \& Rozin, 1970). Further experimentation will be required to differentiate these two possibilities.

Belknap et al. (1977) observed that upon first exposure to a two-bottle (10\% ethanol vs. water) choice situation, DBA mice rapidly developed an ethanol avoidance at a time when the blood ethanol levels averaged $.001 \%(\mathrm{w} / \mathrm{v})$. This very low mean blood ethanol level is unlikely to produce significant postabsorptive aversive effects. Thomas (1969) exposed mice to ascending and descending concentrations of ethanol in a two-bottle choice situation and found that most of the DBA mice avoided the ethanol at concentrations as low as $.01 \%(\mathrm{v} / \mathrm{v})$ and that all of them $(\mathrm{N}=23)$ avoided a $.1 \%$ solution vs. water. This is equivalent to a daily intake, per mouse, of less than $3 \mu \mathrm{l}$ of absolute ethanol for the $.1 \%$ concentration, or about $.1 \mathrm{~g} / \mathrm{kg} / \mathrm{day}$. Significant postabsorptive aversive effects seem unlikely with such small amounts, especially if the ethanol ingestion is distributed throughout a large part of the dark hours. In contrast, the C57 mice did not avoid ethanol until a $30 \%$ concentration was reached (Thomas, 1969).

These studies, as well as the present results, are consistent with the hypothesis that preabsorptive factors play a dominant role in the control of ethanol intake in DBA mice (Belknap et al., 1977), while postabsorptive factors probably predominate in C57 mice (Belknap et al., 1977; Nachman et al., 1971; Rodgers, 1972; Thiessen et al., 1966, 1967).

\section{REFERENCES}

Belknap, J. K., Belknap, N. D., Berg, J. H., \& Coleman, R. Preabsorptive vs. postabsorptive control of ethanol intake in C57BL/6J and DBA/2J mice. Behavior Genetics, 1977, 7, 413-425.

Fuller, J. L. Measurement of alcohol preference in genetic experiments. Journal of Comparative and Physiological Psychology, 1964, 57, 85-88.

FULLER, J. L. Effect of drinking schedule upon alcohol preference in mice. Quarterly Journal of Studies on Alcohol, 1967, 28, 22-26.

Horowitz, G., \& Whitney, G. Alcohol-induced conditioned aversion: Genotypic specificity in mice (Mus musculus). Journal of Comparative and Physiological Psychology, 1975, 89, 340-346.

Kalat, J. W., \& Rozin, P. Salience: A factor which can override temporal contiguity in taste-aversion learning. Journal of Comparative and Physiological Psychology, 1970, 71, 192-197.

LEMAGNEN, J. Alcohol consumption in normal and hyperphagic rats: Orosensory and metabolic factors. In $\mathrm{O}$. Forsander \& K. Eriksson (Eds.), Biological aspects of alcohol consumption. New Brunswick, N.J: Rutgers University Press, 1972.

McClearN, G. E. Genes, generality and behavior research. In J. Hirsch (Ed.), Behavior-genetic analysis. New York: McGraw-Hill, 1967.

McClearN, G. E. Genetics and motivation in the mouse. In Nebraska Symposium on Motivation. Lincoln: University of Nebraska Press, 1968.

NaChman, M., LARue, C., \& LeMagnen, J. The role of olfactory and orosensory factors in the alcohol preference of inbred strains of mice. Physiology and Behavior, 1971, 6, 53-59.

RODGERS, D. Factors underlying differences in alcohol preference in inbred strains of mice. In B. Kissin \& H. Begleiter (Eds.), The biology of alcoholism. New York: Plenum Press, 1972. 
Rodgers, D. A., \& McClearn, G. E. Alcohol preference of mice. In E. Bliss (Ed.), Roots of behavior. New York: Hoeber, 1962.

Rodgers, D., McClearn, G. E., Bennett, E., \& Hebert, M. Alcohol preference as a function of its caloric utility in mice. Journal of Comparative and Physiological Psychology, 1963, 56, 666-672.

SCHLESINGER, K. Genetic and biochemical correlates of alcohol preference in mice. American Journal of Psychiatry, 1966, 122, 767-773.

Schlesinger, K., Kakihana, R., \& Bennett, E. Effects of tetraethylthiuramdisulfide (Antabuse) on the metabolism and consumption of ethanol in mice. Psychosomatic Medicine, 1966, 28, 514-520.

Schneider, C. W., Evans, S. K., Chenoweth, M., \& Beeman, F. Ethanol preference and behavioral tolerance in mice. Journal of Comparative and Physiological Psychology, 1973, 82, 466-474.

Sheppard, J. R., Albersheim, P., \& McClearn, G. E. Enzyme activities and ethanol preference in mice. Biochemical Genetics, 1968, 2, 205-212.

Sheppard, J. R., Albersheim, P., \& McClearn, G. E. Aldehyde dehydrogenase and ethanol preference in mice. Journal of Biological Chemistry, 1970, 245, 2875-2882.
Thiessen, D. D., Whitworth, N., \& Rodgers, D. Reproductive variables and alcohol consumption of the C57BL/Crgl female mouse. Quarterly Journal of Studies on Alcohol, 1966, 27, 591-595.

Thiessen, D. D., Whitworth, N., \& Rodgers, D. Reproductive functions and metabolic capacity as determinants of alcohol preference in C57BL female mice. Journal of Comparative and Physiological Psychology, 1967, 63, 151-154.

Tномаs, K. Selection and avoidance of alcohol solutions by two strains of inbred mice and derived generations. Quarterly Journal of Studies on Alcohol, 1969, 30, 849-861.

Wilson, C. W. M. The limiting factors in alcohol consumption. In O. Forsander \& K. Eriksson (Eds.), Biological aspects of alcohol consumption. New Brunswick, N.J: Rutgers University Press, 1972.

(Received for publication September 23, 1977; revision accepted December 21, 1977.) 